\title{
Gondang Sabangunan in a Death Ceremony of Saur Matua in the Batak Toba Society
}

\section{Aprinaldi Patiaraja Simarangkir, M.Sn}

\author{
IAKN Tarutung - Indonesia \\ april_simorangkir@yahoo.com
}

\begin{abstract}
Gondang Sabangunan has existed since the time of the ancestors which has become a marker that can be read symbolically by the society, in various techniques and styles that appear when it is played. The context of the Gondang Sabangunanhas an important role in the Saur Matuadeath ceremony, namely its role vertically and horizontally. The vertical role is as a medium for the creator or God. While the horizontal role is as a medium between fellow humans. The Batak Toba tribe is a sub or part of the Batak tribes. Batak Toba tribe includes Toba Samosir regency, Lagu Boti, Parsoburan, Humbang Hasundutan, Samosir, North Tapanuli. Batak Toba tribe is one of those in North Sumatra province. It also has its own uniqueness that can be seen from its values and customs which are still maintained today by the people. For the Batak Toba tribe, customs are a sacred thing, which must be obeyed. These values and customs become a basis for the life of the Batak Tobasociety itself.
\end{abstract}

Keywords-Gondang Sabangunan, death ceremony, Saur Matua, Batak Toba Society.

\section{INTRODUCTION}

Basically a group society has its own culture. It is a learning process and adjustments that exist on the basis of individual and collective values. A culture in a place is the values of the learning process of the man himself, so that differences become certain things because of understanding, interpreting and adjusting humans or groups is different, especially the dynamic nature of human beings. So that culture is a finished result of a long process that occurs. In this case, the Batak Tobasociety is a case study of existing problems. Batak Tobaas a society group have their own systems and adjustments as cultural values they have. As is the case, it is the tradition of gondang sabangunan.Thus things in ethnic arts are an integral part of people's lives in general, Batak Toba traditional music is 'original music' (original) or in the language of the Batak Toba region called 'musik gondang'which is music originating from Batak Toba, musical words give different meanings to gondang words. Although gondang words have the same meaning, namely music, but the purpose of using musical words with gondang is not the same. Music words are associated with modern music while gondang words are associated with traditional music. Batak Toba is one of tribe found in Tapanuli, located in North Sumatra province. In the a traditional death ceremony of saur matuaperformed by the Batak Tobasociety, that gondang sabangunanserves as a accompaniment to the dance (tortor) and also as a medium to achieve a desired goal in the death ceremony. Saur matua is a person who dies whether the husband or wife whose sons and daughters are married and have grandchildren both from their sons and from their children. Talking about the dalihan na tolu (kinship structure) and tortor (traditional dances) customs is very important because the dalihan na tolu, gondang sabangunan and tortor customs are inseparable in the execution of the traditional saur matua ceremony.The context of the gondang sabangunan has an important role in the death ceremony of saur matua, namely the role of gondang sabangunan vertically and horizontally. The vertical role is as a medium for the creator or God. Whereas the horizontal role is as a medium between fellow humans (specifically the respect between the elements of dalihan na tolu namely hula-hula (in-laws), dongan tubu (male family), and boru (son-in-law). The death ceremony of the saur matua is that the existence of gondang saur matua is very relevant in the elements of dalihan na tolu at the traditional death ceremony of saur matua, because the Batak Toba people want to achieve the values of life in the dalihan na tolu, hagabeon (having descendants), hamoraon (wealth), hasangapon (prestigious). These three values are the strength, continuity, and perfection of the dalihan na tolu custom at the death ceremony of saur matua.The strength of the aesthetic values contained in the gondang sabangunan is a wealth for the formation of human mental spiritual towards a dignified and religious life. Because the sound effect of gondang sabangunan is a sound that is not only regular in terms of musical aesthetics, but has a psychologicalmessage that can touch the feelings and souls 
of those who hear, in reality, when someone (society) hears the rhythm of music with a fast tempo, dynamically, the person who hears music that is played will influence his emotional state to be excited. Conversely with a slow rhythm, people will be able to feel the atmosphere that is calm and solemn.Therefore gondang sabangunan is the result of thought, work, human initiative is useful and good for the future of its own culture, as well as for the future of the world in general, therefore the Batak Tobasociety must preserve and appreciate gondang sabangunan as traditional Batak Toba music, because gondang sabangunan is expressed as a ray of grace and God's creation to humans and the world.From the previous explanation, the author purposes the research question as follows: What is the existence of gondang sabangunan function in the death ceremony of saur matua? The objectives of research are to find out the function of gondang sabangunan in the death ceremony of saur matua in the Batak Tobasociety and to explain the role of the relevance of gondang sabangunan on dalihan na tolu at the death ceremonyof saur matua.This research is also expected to be useful for readers, both those in the church's musical disciplines, as well as outside, and especially for the writers themselves in adding insight into Batak Toba culture.

\section{REVIEW OF RELATED LITERATURE}

Merriam (1964: 120) states the use and function of music, where it means thatemphasizes the problem of the situation or the way that the music is used, while the functionemphasizes the reasons for the use or purpose of the use of music, especially the broader purpose; to what extent is music capable of meeting human needs themselves. In the communication function of the death ceremony ofsuar matua, gondangsabangunanhas a function as an accompaniment to tortor (dancing) and as an intermediary medium to the creator or God (vertical) and as a medium of mediation between fellow humans or dalihan natolu (horizontal). The Batak Tobasociety believes that through Gondang Sabangunan all prayers and requests can be conveyed to the creator or God. He also argues that change can also be seen as the beginning of a culture caused by the existence of two factors, namely internal factors and external factors. In this case the most influential factor on the changes that occur in the gondang sabangunan is external factors. While internal changes are changes that arise from within and carried out by the actors of culture themselves.According to Tylor, culture is a complex whole formed in history and has been passed on from generation to generation through tradition. The traditional organization includes social, economic, religious, belief, customs, legal, artistic, technical and gondangsabangunan in the death ceremony of saur matua that has existed since the time of the ancestors has become a symbolic and can be read by the supporting society groups, in various the technique and style that appears when gondang is played.

\section{RESEARCH METHOD}

This study used a descriptive analytical method with a qualitative approach, aimed at describing the position and function of the existence of the Gondang Sabangunan ensemble in the death ceremony of the Saur Matua.Research data was obtained from observations and interviews, as well as from the available library sources. The nature of qualitative data is rich, multi-dimensional and complex. This study did not question the population sample as in quantitative research. In collecting data that can later be used to answer all problems by means of field work. In the field research, the author directly interacted with musicians, traditional elders and Batak Toba people, and sought references to the literature related to this research.

\section{RESULT AND DISCUSSION}

4.1 Functions of Gondang Sabangunan As Aesthetics

According to Hadi (2000) the experience of religion and aesthetic experience (art) as one form of human behavior, because religion as well as art together have the power to shape the dignity, personality and moral of humans. Art and religion are very full of teachings of kindness, truth, happiness and beauty as a very substantial part of human existence. Some of the views of the Batak Tobasociety, experience and attitude of spirituality and expression cannot be separated from the existence of music as an element of art. This view also hints at the importance of musical aesthetics in the death ceremony of saur matua, the presence and position of gondang sabangunanin traditional ceremonies not just to fulfill the needs as a tortor, but how it can be worked in such a way that it fulfills the meaning and value high aesthetics.The art of music in the Batak Tobasociety has a lot of diversity as found in several Batak ethnic groups including gondang sabangunan, gondang hasapi from Batak Toba, gordang sambilan from Mandailing Batak, perkolong-kolong from Batak Karo, and others from Batak Simalungun. We can also see the diversity of musical art from several repertoires of the regional musical instruments, each musical instrument has its own differences and specificities depending on the place where the art is located.The art of dance and music of the Batak people are also known for their expertise in the matter 
of handicrafts such as carving we can see the form of carving Batak Toba in gorga (decorative reliefs) contained in his traditional house. Batak Gorga symbolizes Debata Na Tolu, with the power of Mula Jadi Nabolon. Red, white and black gorga colors and the shape of gorga become a hope, prayer and ideals. Other examples are classified as handicrafts such as those found in carved sculptures in the form of atunggal panaluan (stick).In addition, there is also a well-known art of handicraft, namely martonun ulos (ulos weaving). For the societyBatak Toba Ulos is one of the most important things. Ulos becomes an identity in addition to the ulos clan having different types and roles in each traditional ceremony.In the execution of the saur matua ceremonies, how can these elements of creativity be placed in their respective places we can see clearly. Both as a supporter and as something basic in the implementation of the ceremony. When someone dies, the bones will give ulos, called sap ulos. At the time of administration of ulos, the bone group that will give ulos first asks for gondang and then manages them together. Ulos is also used by other mourners both family members and just relatives as a sign of grieving. From this we can see how the relationship between adat and Batak Tobaart. Where adat and art become one complementary entity. By guarding and implementing adat, traditional arts will also automatically be maintained.

4.2 Functions of Gondang in the Development of Social Identity

Gondang Sabangunan is as a result of thought, work, human initiative which began to emerge in the form of ideas and then manifested through expressions having a very strong social function in the traditional ceremony of the death of saur matua. It is said that because the creation of works of art is thus an understanding of the meanings of life that exist between humans (Ratna, 2003:8). One of the functions found is gondang sabangunan as a form of a sense of society or society togetherness which is part of the humanitarian problem.The humanitarian function that is groomed by gondang sabangunan and found in reality on the ground is that the principle of life is mutually helpful, called communion or society, which means that groups of people who join in gondang sabagunan are not only for the sake of the service of musical ceremonies, but are formed cooperation helps each other and helps each other in turn for a job from each member in the gondang sabangunan group. For example, when the ceremony of death ceremonies has not been carried out, each member must prepare and pay attention to their respective instruments and sound system so that the results of the sound quality are pleasant to hear at the time of the customary ceremony of the death saur matua.In organizing the saur matua traditional ceremony, it is a matter of pride for the family when it is able to carry out the amount of funds needed starting from preparation, organizing until the completion of the event still requires funds. So from this it is not uncommon for families who cannot afford to hold this ceremony and for those who can afford it can be considered as a measure of social identity in other words the ability of a family to hold this ceremony might be a measure of the success they get.

4.3 The Function of Gondang Sabangunan As Education Covering the 3 functions described above, namely ritual, aesthetics, sociology that in gondang sabangunan which can also be a concern and become a strong concentration is done is the function of education. Referring to the opinion of Benjamin S. Bloom in a theory called "Bloom's taxonomy" which is the domain of cognitive, affection, and phsikomotoris (Djaali, 2009: 99). That cognitive aspects that are knowledge, affection or attitude and phsikomotoris that are skillful, and scale are aspects that become educational programs and knowledge about gondang sabangunan in Batak Tobasociety. In the process of becoming a gondang sabangunan player, the aspect that must be cultivated is a sense of love and an understanding of high appreciation of the wealth of traditions in the Batak Toba culture. A sense of appreciation and appreciation for gondang sabangunan as an instrument of Batak Toba culture which is in the midst of technological advancements and increasingly strong global transformation is felt with the presence of modern music technology products that develop and influence in the midst of society. Then the formation of knowledge of music theory and skills self. The gondang sabangunan players teach all the meanings and meanings contained in the gondang sabangunan which is historical, philosophical and musical values and cultural values contained in the gondang sabangunan. So that it can make the younger generation know and know the meaning and meaning of their own culture. So that young people can form professional abilities so that the younger generation has adequate self-confidence and social stability in the midst of society.According to Davis and Moore (2004:118) that social stratification is a universal and important phenomenon. They claim that no society is not stratified or completely classless. Stratification is a functional necessity, all communities need the system and its needs lead to a system of staratification.Based on this understanding it is stated that the group of gondang sabangunan traditional 
music players has a high social security position in the midst of people's lives.

\section{CONCLUSION}

The death ceremony of Saur MatuaFor the Batak Tobasocietyis a type of death that is desired and dreamed that has a contextual understanding, namely someone who dies in the world in old age, has sons and daughters, grandchildren from a son and from a daughter, and no more children without a family. Therefore, the death of saur matua is not to show the sadness of his descendants, however, the ceremony of death is to express the joyfull.The presence of gondang sabangunan players during the traditional death ceremony of saur matua among Batak Toba people were 1) the official invitation of the party whose celebration was held after being agreed upon together on the amount of money agreed upon before hand, 2) The presence of gondang musicians in the construction of Batak Toba will be held a special traditional ceremony, to welcome the arrival of gondang sabangunanmusicians.In fact at the present time, the frequency of using gondang sabangunan in the traditional death ceremony of of saur matua in the Silaen district Sitorang village, often combined with modern musical instruments, such as electric guitars, drum sets, keyboards, trumpets, and saxophone.Today, the use of gondanng sabangunan is only a situation that involves gondang as an entertainment event.The function of the gondang sabangunan in the ceremony of the death of saur matua in the Batak Tobasociety is an absolute part and must receive attention from the local government as the institute and the entire Batak Tobasociety. Gondang sabangunan which is a supporting facility in the death saur matua traditional ceremony, the stronger its position when the substance is understood in more depth, and how the local government attempts to be realistic about the times and society in the midst of a new era hegemony which offers various changes, at the same time requires agencies and communities to take a multi role in various situations.

\section{REFERENCES}

[1] Djaali, H. (2000). Psikologi Pendidikan. Jakarta: Universitas Negeri Jakarta.

[2] Dyson, L. (1987). Manusia dan Seni Budaya. Jakarta: Balai Pustaka.

[3] Endraswara, S. (2003). Metodologi Penelitian Kebudayaan. Yogyakarta: Gadja Mada University Press.

[4] Gultom, R. D. J. (1995).Dalihan Na Tolu Nilai Budaya Suku Batak. Medan: CV Armada.
[5] George, R, Goodman, D. J. (2004). Teori Sosiologi Modern, Tranlated by Tribowo Budi Santosa (ed), Jakarta: Prenada Media.

[6] Hadi, S. Y. (2000).Seni Dalam Ritual Agama.Yogyakarta: Yayasan untuk Indonesia.

[7] Koentjaraningrat. (1981). Metode Penelitian Masyarakat. Jakarta: Balai Pustaka.

[8] Merriam, A. P. (1964). The Anthropology of Music. Chicago:Northwestern University Press.

[9] Moleong, L. J (2000). Metodologi Penelitian Kualitatif.Bandung: PT Remaja Rosdakarya.

[10] Nettl, B. (1964). Theory and Method in Ethnomusikilogy. New York: The Free Press.

[11] Okazaki, Y (1987). Music Identity and Religious Change Among The Batak People OfNorth Sumatera, Desertation, University of Califonia, Los Angel.

[12] Pasaribu, B. M. (1986). Tagading Batak Toba: Suatu kajian dalam Konteks Gondang Sabangunan, Unpublish Thesis, Fakultas sastra Jurusan Etnomusikologi USU Medan.

[13] Ratna, N. K. (2003).Paradigma Sosiologi Sastra.Yogyakarta: Pustaka Pelajar. 